\title{
A New Fuzzy Comprehensive Evaluation Model for Influencing Factors of Physical Education
}

\author{
https://doi.org/10.3991/ijet.v16i17.25655 \\ Min Tang( $\left.{ }^{\bowtie}\right)$, Xiaoxue Si, Ruixue Wang, Wenzhi Gao \\ Suihua University, Suihua, China \\ gwz102424@163.com
}

\begin{abstract}
Education evaluation promotes the scientific management of physical education (PE), and facilitates the realization of teaching goals of PE lessons. Through fuzzy comprehensive evaluation (FCE), this paper explores the influencing factors of teaching evaluation system for PE. A new evaluation index system (EIS) of PE was constructed through expert evaluation, the weight values of each index were determined through analytic hierarchy process (AHP), and an FCE model was established for PE. Taking a college PE teacher as the research object, the application effect of the proposed FCE model was empirically investigated. The results demonstrate the practicality and feasibility of the proposed model. The FCE model can qualify PE evaluation results comprehensively, and support the overall evaluation of a single factor. The modeling results reflect the actual teaching effect from multiple layers, and help to rationalize PE in the light of specific factors. The research provides important theoretical and realistic evidence to the promotion of PE evaluation.
\end{abstract}

Keywords - analytic hierarchy process (AHP), fuzzy comprehensive evaluation (FCE), physical education (PE), teaching evaluation system

\section{Introduction}

As education reform is being promoted and deepened constantly in China in recent years, the teaching philosophy, teaching modes, and teaching methods of PE have been reformed in an all-round way. To test whether these reforms are scientific, reasonable, and effective, corresponding evaluation means are required, and the education evaluation is of crucial importance to the management, decision-making, development, and reform of education. Now, education evaluation has become an important part of education works, therefore, establishing suitable PE evaluation systems are of great necessity.

Studies have shown that education evaluation originated in China [1]. Ever since China has determined the education goals of developing quality education, focusing on students' physical quality growth, and cultivating students to have a life-long habit of physical exercise, domestic education scholars have gradually turned their eyes on the research of PE evaluation, and many of them have conducted related research from different perspectives and achieved fruitful results. For example, some explored 
the theories, methods, and status quo of PE evaluation [2]; some analyzed the influencing factors of PE evaluation [3]; some constructed various EISs for PE evaluation, and employed real cases to perform empirical research [4]. However, currently, there isn't a uniform standard for PE evaluation in China, and the existing PE generally emphasizes too much on the lecturing of PE knowledge and skills, while ignoring the evaluation on the students' physical quality, ability, and interest, moreover, the evaluation subjects are not as varied [5]. Foreign research's PE evaluation is more systematic and comprehensive, and can reflect PE students' learning attitude, ability, interest, and individual development [6]. For example, the United States have adopted an alternative PE evaluation method which lays stress on students' ability in applying PE knowledge and skills in practice [7]; the Japanese respects individual differences during PE evaluation, they formulated personalized evaluation criteria to trigger students' PE learning enthusiasm [8].

After carefully reviewing and analyzing relevant literatures, this paper established a new EIS for PE evaluation, and constructed a PE evaluation model based on FCE; then, the proposed model was subject to empirical study to verify their feasibility and practicality.

\section{About the new EIS}

Besides research papers, we also analyzed relevant documents issued by the Chinese government, and determined a few evaluation indexes from four aspects of teaching preparation, teaching process, teaching effect, and teaching evaluation according to four evaluation principles of scientificity, comprehensiveness, objectivity, and feasibility [9]. After consulting opinions of experts and teachers, at first, an EIS with 4 first-level indexes, 11 second-level indexes, and 30 third-level indexes was established initially. Then, experts were invited to screen the indexes and determine their importance, and 2 third-level indexes had been deleted per their opinions; finally, an EIS with 4 first-level indexes, 11 second-level indexes, and 28 third-level indexes was established, as shown in Table 1 [10].

Table 1. EIS and index weight

\begin{tabular}{|c|c|c|}
\hline $\begin{array}{c}\text { First-level } \\
\text { index (weight) }\end{array}$ & $\begin{array}{l}\text { Second-level index } \\
\text { (weight) }\end{array}$ & Third-level index (weight) \\
\hline \multirow{6}{*}{$\begin{array}{l}\text { Teaching } \\
\text { preparation } \\
\mathrm{U}_{1}(0.202)\end{array}$} & \multirow{3}{*}{$\begin{array}{l}\text { Teaching file } \\
\mathrm{U}_{11}(0.341)\end{array}$} & $\begin{array}{l}\text { Clear teaching objectives and reasonable outline } \\
\qquad U_{111}(0.334)\end{array}$ \\
\hline & & $\begin{array}{c}\text { Reasonable lesson plan } \\
\mathrm{U}_{112}(0.270)\end{array}$ \\
\hline & & $\begin{array}{l}\text { Clear teaching plan } \\
\mathrm{U}_{113}(0.525) \\
\end{array}$ \\
\hline & \multirow[t]{2}{*}{$\begin{array}{l}\text { Conditions and facilities } \\
\qquad \mathrm{U}_{12}(0.303)\end{array}$} & $\begin{array}{l}\text { Reasonable venue arrangement } \\
\qquad \mathrm{U}_{121}(0.428)\end{array}$ \\
\hline & & $\begin{array}{l}\text { Equipment meets teaching needs } \\
\mathrm{U}_{122}(0.572)\end{array}$ \\
\hline & Academic analysis & Master the level of students' sports skills \\
\hline
\end{tabular}


Paper-A New Fuzzy Comprehensive Evaluation Model for Influencing Factors of Physical Education

\begin{tabular}{|c|c|c|}
\hline & $\mathrm{U}_{13}(0.356)$ & $\mathrm{U}_{131}(0.500)$ \\
\hline & & $\begin{array}{l}\text { Understand the physical fitness of students } \\
\qquad U_{132}(0.500)\end{array}$ \\
\hline \multirow{10}{*}{$\begin{array}{l}\text { Teaching } \\
\text { process } \\
\mathrm{U}_{2}(0.431)\end{array}$} & \multirow{3}{*}{$\begin{array}{l}\text { Teaching content } \\
\quad \mathrm{U}_{21}(0.237)\end{array}$} & $\begin{array}{l}\text { The teaching content is rich and targeted } \\
\qquad \mathrm{U}_{211}(0.364)\end{array}$ \\
\hline & & $\begin{array}{l}\text { Knowledge and skills reflect coherence } \\
\mathrm{U}_{212}(0.215)\end{array}$ \\
\hline & & $\begin{array}{c}\text { Focused, moderate difficulty } \\
\mathrm{U}_{213}(0.421)\end{array}$ \\
\hline & \multirow{2}{*}{$\begin{array}{l}\text { teaching method } \\
\mathrm{U}_{22}(0.357)\end{array}$} & $\begin{array}{l}\text { Flexible teaching methods, suitable for the characteristics of } \\
\text { the course } \\
\qquad U_{221}(0.376)\end{array}$ \\
\hline & & $\begin{array}{l}\text { Teach students in accordance with their aptitude, pay atten- } \\
\text { tion to the cultivation of methods and abilities } \\
\qquad U_{222}(0.624)\end{array}$ \\
\hline & \multirow{3}{*}{$\begin{array}{l}\text { Teaching organization } \\
\mathrm{U}_{23}(0.305)\end{array}$} & $\begin{array}{l}\text { Reasonable curriculum structure and exercise load } \\
\qquad U_{231}(0.478)\end{array}$ \\
\hline & & $\begin{array}{l}\text { Reasonable use of venue equipment } \\
\mathrm{U}_{232}(0.233)\end{array}$ \\
\hline & & $\begin{array}{c}\text { Student-oriented } \\
\mathrm{U}_{233}(0.289) \\
\end{array}$ \\
\hline & \multirow{2}{*}{$\begin{array}{l}\text { Teaching attitude } \\
\quad \mathrm{U}_{24}(0.201)\end{array}$} & $\begin{array}{l}\text { Correct teaching attitude and clear teaching ideas } \\
\qquad U_{241}(0.417)\end{array}$ \\
\hline & & $\begin{array}{c}\text { Accurate language, standardized and graceful demonstration } \\
\text { actions } \\
\mathrm{U}_{242}(0.583)\end{array}$ \\
\hline \multirow{5}{*}{$\begin{array}{l}\text { Teaching effect } \\
\mathrm{U}_{3}(0.178)\end{array}$} & \multirow{2}{*}{$\begin{array}{c}\text { Student sports knowledge } \\
\text { and skills } \\
\mathrm{U}_{31}(0.423)\end{array}$} & $\begin{array}{c}\text { Master relevant sports knowledge } \mathrm{U}_{311} \\
(0.500) \\
\end{array}$ \\
\hline & & $\begin{array}{c}\text { Master sports skills } \\
\mathrm{U}_{312}(0.500)\end{array}$ \\
\hline & \multirow{3}{*}{$\begin{array}{l}\text { Student learning attitude } \\
\mathrm{U}_{32}(0.577)\end{array}$} & $\begin{array}{l}\text { Consciously participate in sports activities } \\
\qquad \mathrm{U}_{321}(0.393)\end{array}$ \\
\hline & & $\begin{array}{l}\text { Have expectations for physical education } \\
\qquad U_{322}(0.181)\end{array}$ \\
\hline & & $\begin{array}{l}\text { Develop good physical exercise habits } \\
\qquad \mathrm{U}_{323}(0.426)\end{array}$ \\
\hline \multirow{6}{*}{$\begin{array}{l}\text { Teaching } \\
\text { Evaluation } \\
\mathrm{U}_{4}(0.189)\end{array}$} & \multirow{2}{*}{$\begin{array}{l}\text { Instant evaluation } \\
\qquad \mathrm{U}_{41}(0.483)\end{array}$} & $\begin{array}{l}\text { Correct errors in a timely and effective manner } \\
\qquad \mathrm{U}_{411}(0.387)\end{array}$ \\
\hline & & $\begin{array}{l}\text { Encourage and evaluate to cultivate students' interest } \\
\qquad \mathrm{U}_{412}(0.613)\end{array}$ \\
\hline & \multirow{2}{*}{$\begin{array}{l}\text { Formative evaluation } \\
\qquad \mathrm{U}_{42}(0.315)\end{array}$} & $\begin{array}{l}\text { Achievement of teaching goals } \\
\qquad \mathrm{U}_{421}(0.325)\end{array}$ \\
\hline & & $\begin{array}{c}\text { Students' knowledge and skills mastery } \\
\mathrm{U}_{422}(0.675)\end{array}$ \\
\hline & \multirow{2}{*}{$\begin{array}{l}\text { Summative evaluation } \\
\qquad \mathrm{U}_{43}(0.202)\end{array}$} & $\begin{array}{l}\text { Evaluate students objectively and impartially } \\
\qquad \mathrm{U}_{431}(0.532)\end{array}$ \\
\hline & & $\begin{array}{l}\text { Test the suitability of teaching objectives and syllabus } \\
\qquad U_{432}(0.468)\end{array}$ \\
\hline
\end{tabular}




\section{About the FCE-based PE evaluation model}

\subsection{Determination of index weight values}

This paper used AHP to determine the weight values of indexes at each level. First, the EIS was constructed, and the hierarchical relationships among the indexes were analyzed. Then, 15 experts and teachers who are familiar with the teaching evaluation of the PE major were invited to use 1-5 scales to compare the indexes in pairs and construct the corresponding judgement matrix, as shown in Table 2 [11]. After that, the judgement matrix was calculated, normalized, and subject to consistency test. If the matrix passes the consistency test, it means that the calculated weight coefficients are reasonable, and it can reflect the relative importance of each index in the EIS; if the matrix fails to pass the consistency test, it needs to be re-adjusted until it could pass the consistency test [12].

Table 2. The 1-9 scaling method

\begin{tabular}{|l|c|}
\hline \multicolumn{1}{|c|}{ Scale value } & Meaning \\
\hline 1 & Two factors are equally important \\
\hline 3 & The former is slightly more important than the latter \\
\hline 5 & The former is more important than the latter \\
\hline 7 & The former is obviously more important than the latter \\
\hline 9 & The former is absolutely more important than the latter \\
\hline $1,4,6,8,10$ & Importance lies between two adjacent levels \\
\hline $1,1 / 2,1 / 3, \ldots, 1 / 9$ & The latter takes the reciprocal of the importance of the former \\
\hline
\end{tabular}

With the second-level index "teaching file" under the first-level index "teaching preparation" as an example, an expert judgement matrix was constructed:

$$
A_{11}=\left[\begin{array}{ccc}
1 & 3 & 1 / 2 \\
1 / 3 & 1 & 1 / 3 \\
2 & 3 & 1
\end{array}\right]
$$

After calculating and normalizing the expert judgement matrix, it's obtained:

$$
w_{11}=\left[\begin{array}{l}
0.334 \\
0.270 \\
0.525
\end{array}\right]
$$

According to Formula (1)- (3), after calculation, it's obtained $\lambda_{\max }=4.741$, $C R=0.082<0.1$, which mean that the judgement matrix is consistent, and the assigned weight values could reflect the importance degree of each index [13]. Using the same method, the weight values of other indexes could be obtained as well, the details are listed in Table 1. 


$$
\begin{gathered}
\lambda \max =\frac{1}{n} \sum_{i=1}^{n}\left[\frac{\sum_{j=1}^{n} a i j w i j}{w j}\right] \\
C I=\frac{\lambda \max -n}{n-1} \\
C R=\frac{C I}{R I}
\end{gathered}
$$

$R I$ is the random index, and its value could be obtained by looking up the table; according to the condition in this study, when $\mathrm{n}=4, R I$ value is 0.9 [14].

\subsection{Construction of the FCE-based PE evaluation model}

1. Construction of the evaluation factor sets

Based on above-established EIS for PE evaluation, the evaluation set of first-level indexes could be obtained as:

$$
U=\left\{U_{1}, U_{2}, U_{3}, U_{4}\right\}
$$

The evaluation sets of second-level indexes could be obtained as:

$$
\begin{aligned}
& U_{1}=\left\{U_{11}, U_{12}, U_{13}\right\}, U_{2}=\left\{U_{21}, U_{22}, U_{23}, U_{24}\right\}, \\
& U_{3}=\left\{U_{31}, U_{32}\right\}, U_{4}=\left\{U_{41}, U_{42}, U_{43}\right\} .
\end{aligned}
$$

The evaluation sets of third-level indexes could be obtained as:

$$
\begin{aligned}
& U_{11}=\left\{U_{111}, U_{112}, U_{113}\right\}, U_{12}=\left\{U_{121}, U_{122}\right\}, U_{13}=\left\{U_{131}, U_{132}\right\} \\
& U_{21}=\left\{U_{211}, U_{212}, U_{213}\right\}, U_{22}=\left\{U_{221}, U_{222}\right\}, U_{23}=\left\{U_{231}, U_{232}, U_{233}\right\}, \\
& U_{24}=\left\{U_{241}, U_{242}\right\}, U_{31}=\left\{U_{311}, U_{312}\right\}, U_{32}=\left\{U_{321}, U_{322}, U_{323}\right\}, \\
& U_{41}=\left\{U_{411}, U_{412}\right\}, U_{42}=\left\{U_{421}, U_{422}\right\}, U_{43}=\left\{U_{431}, U_{432}\right\} .
\end{aligned}
$$

2. Construction of the weight value sets

Through the AHP mentioned in above paragraphs, the weight values of indexes at each level could be obtained:

$$
\begin{aligned}
& w_{11}=\{0.334,0.270,0.525\}, w_{12}=\{0.428,0.572\}, w_{13}=\{0.500,0.500\}, \\
& w_{21}=\{0.364,0.215,0.421\}, w_{22}=\{0.376,0.624\}, w_{23}=\{0.478,0.233,0.289\} \\
& w_{24}=\{0.417,0.583\}, w_{31}=\{0.500,0.500\}, w_{32}=\{0.393,0.181,0.426\},
\end{aligned}
$$




$$
w_{41}=\{0.387,0.613\}, w_{42}=\{0.325,0.675\}, w_{42}=\{0.532,0.468\}
$$

3. Construction of the comment set:

The constructed comment set is:

$$
V=\{V 1, V 2, V 3, V 4, V 5\}=\{\text { Excellent }, \text { Good,Moderate,Pass }\}
$$

Its corresponding value set is:

$$
N=\left\{N_{1}, N_{2}, N_{3}, N_{4}\right\}
$$

Table 3 lists the scores corresponding to the value set [15].

Table 3. Scores of the value set

\begin{tabular}{|c|c|c|c|c|}
\hline Evaluation grade & Excellent & Good & Average & Pass \\
\hline Scores & 95 & 85 & 75 & 65 \\
\hline
\end{tabular}

4. Construction of the FCE matrix

First, the fuzzy evaluation sets of each single index in the EIS were determined:

$$
\begin{gathered}
R_{1}=\left(r_{11}, r_{12}, \cdots r_{1 m}\right) \\
R_{2}=\left(r_{21}, r_{22}, \cdots r_{2 m}\right) \\
\cdots \\
R_{n}=\left(r_{n 1}, r_{n 2}, \cdots r_{n m}\right)
\end{gathered}
$$

Then, the valuation matrix $R_{i}$ of a certain single factor $i$ was constructed:

$$
R_{i}=\left[\begin{array}{cccc}
r_{i 11} & r_{i 12}, & \cdots & r_{i 1 m} \\
r_{i 21} & r_{i 22} & \cdots & r_{i 2 m} \\
\cdots & \cdots & \cdots & \cdots \\
r_{i n 1} & r_{i n 2} & \cdots & r_{i n m}
\end{array}\right]
$$

According to the fuzzy transformation principle, the second-level FCE set could be calculated:

$$
B_{i}=w_{i} \times R_{i}=\left[w_{1}, w_{2}, \cdots w_{m}\right] \times\left[\begin{array}{cccc}
r_{i 11} & r_{i 12}, & \cdots & r_{i 1 m} \\
r_{i 21} & r_{i 22} & \cdots & r_{i 2 m} \\
\cdots & \cdots & \cdots & \cdots \\
r_{i n 1} & r_{i n 2} & \cdots & r_{i n m}
\end{array}\right]
$$

Thus, the first-level FCE set could be obtained as: 


$$
R=\left[\begin{array}{c}
B_{1} \\
B_{2} \\
\cdots \\
B_{m}
\end{array}\right]
$$

5. The quantified score of the comprehensive evaluation is:

$$
S=B \times V^{T}
$$

\subsection{A empirical study on the proposed model}

To verify the practicality and feasibility of the proposed EIS and model, a PE teacher A was selected as an evaluation object, and 10 supervisors were invited to attend the class taught by teacher $\mathrm{A}$ and give evaluations on the teacher using the proposed EIS, the evaluation results are shown in Table 4, the values in the table represent the number of supervisors who had chosen the corresponding option.

\begin{tabular}{|c|c|c|c|c|c|c|}
\hline \multirow{2}{*}{$\begin{array}{c}\text { First-level } \\
\text { index } \\
\text { (weight) }\end{array}$} & \multirow{2}{*}{$\begin{array}{c}\text { Second-level } \\
\text { index (weight) }\end{array}$} & \multirow{2}{*}{ Third-level index (weight) } & \multicolumn{4}{|c|}{ Evaluation grade } \\
\hline & & & Excellent & Good & Moderate & Pass \\
\hline \multirow{7}{*}{$\mathrm{U} 1(0.202)$} & \multirow{3}{*}{$\mathrm{U} 11(0.341)$} & $\begin{array}{c}\text { Clear teaching objectives and reasona- } \\
\text { ble outline } \\
\text { U111(0.334) }\end{array}$ & 6 & 3 & 1 & 0 \\
\hline & & $\begin{array}{c}\text { Reasonable lesson plan } \\
\text { U112(0.270) }\end{array}$ & 7 & 2 & 1 & 0 \\
\hline & & $\begin{array}{c}\text { Clear teaching plan } \\
\text { U113(0.525) }\end{array}$ & 7 & 1 & 2 & 0 \\
\hline & \multirow{2}{*}{$\mathrm{U} 12(0.303)$} & $\begin{array}{l}\text { Reasonable venue arrangement } \\
\text { U121(0.428) }\end{array}$ & 6 & 3 & 0 & 1 \\
\hline & & $\begin{array}{l}\text { Equipment meets teaching needs } \\
\text { U122(0.572) }\end{array}$ & 5 & 4 & 1 & 0 \\
\hline & \multirow{2}{*}{$\mathrm{U} 13(0.356)$} & $\begin{array}{c}\text { Master the level of students' sports } \\
\text { skills } \\
\text { U131(0.500) }\end{array}$ & 4 & 3 & 2 & 1 \\
\hline & & $\begin{array}{c}\text { Understand the physical fitness of } \\
\text { students } \\
\text { U132(0.500) }\end{array}$ & 5 & 2 & 3 & 0 \\
\hline \multirow{4}{*}{$\mathrm{U} 2(0.431)$} & \multirow{3}{*}{$\mathrm{U} 21(0.237)$} & $\begin{array}{l}\text { The teaching content is rich and target- } \\
\text { ed } \\
\text { U211(0.364) }\end{array}$ & 7 & 3 & 0 & 0 \\
\hline & & $\begin{array}{l}\text { Knowledge and skills reflect coherence } \\
\text { U212(0.215) }\end{array}$ & 6 & 3 & 1 & 0 \\
\hline & & $\begin{array}{c}\text { Focused, moderate difficulty } \\
\text { U213(0.421) }\end{array}$ & 5 & 3 & 1 & 1 \\
\hline & $\mathrm{U} 22(0.357)$ & $\begin{array}{l}\text { Flexible teaching methods, suitable for } \\
\text { the characteristics of the course } \\
\text { U221(0.376) }\end{array}$ & 7 & 3 & 0 & 0 \\
\hline
\end{tabular}

Table 4. Statistics of PE evaluation results 
Paper-A New Fuzzy Comprehensive Evaluation Model for Influencing Factors of Physical Education

\begin{tabular}{|c|c|c|c|c|c|c|}
\hline & & $\begin{array}{c}\text { Teach students in accordance with their } \\
\text { aptitude, pay attention to the cultivation } \\
\text { of methods and abilities } \\
\text { U222(0.624) }\end{array}$ & 6 & 3 & 1 & 0 \\
\hline & \multirow{3}{*}{ U23(0.305) } & $\begin{array}{c}\text { Reasonable curriculum structure and } \\
\text { exercise load } \\
\text { U231(0.478) }\end{array}$ & 5 & 2 & 2 & 1 \\
\hline & & $\begin{array}{l}\text { Reasonable use of venue equipment } \\
\text { U232(0.233) }\end{array}$ & 6 & 2 & 2 & 0 \\
\hline & & $\begin{array}{l}\text { Student-oriented } \\
\mathrm{U} 233(0.289)\end{array}$ & 4 & 2 & 3 & 1 \\
\hline & \multirow{2}{*}{ U24(0.201) } & $\begin{array}{c}\text { Correct teaching attitude and clear } \\
\text { teaching ideas } \\
\text { U241(0.417) }\end{array}$ & 8 & 1 & 1 & 0 \\
\hline & & $\begin{array}{c}\text { Accurate language, standardized and } \\
\text { graceful demonstration actions } \\
\text { U242(0.583) }\end{array}$ & 7 & 2 & 1 & 0 \\
\hline \multirow{5}{*}{$\mathrm{U} 3(0.178)$} & \multirow{2}{*}{ U31(0.423) } & $\begin{array}{c}\text { Master relevant sports knowledgeU311 } \\
(0.500)\end{array}$ & 6 & 2 & 2 & 0 \\
\hline & & $\begin{array}{c}\text { Master sports skills } \\
\text { U312(0.500) }\end{array}$ & 5 & 3 & 2 & 0 \\
\hline & \multirow{3}{*}{$\mathrm{U} 32(0.577)$} & $\begin{array}{c}\text { Consciously participate in sports activi- } \\
\text { ties } \\
\text { U321(0.393) }\end{array}$ & 7 & 2 & 1 & 0 \\
\hline & & $\begin{array}{l}\text { Have expectations for physical educa- } \\
\text { tion } \\
\text { U322(0.181) }\end{array}$ & 5 & 3 & 1 & 1 \\
\hline & & $\begin{array}{l}\text { Develop good physical exercise habits } \\
\text { U323(0.426) }\end{array}$ & 4 & 4 & 1 & 1 \\
\hline \multirow{6}{*}{ U4(0.189) } & \multirow{2}{*}{ U41(0.483) } & $\begin{array}{c}\text { Correct errors in a timely and effective } \\
\text { manner } \\
\mathrm{U} 411(0.387)\end{array}$ & 6 & 3 & 0 & 1 \\
\hline & & $\begin{array}{c}\text { Encourage and evaluate to cultivate } \\
\text { students' interest } \\
\text { U412(0.613) }\end{array}$ & 5 & 3 & 2 & 0 \\
\hline & \multirow{2}{*}{$\mathrm{U} 42(0.315)$} & $\begin{array}{c}\text { Achievement of teaching goals } \\
\text { U421(0.325) }\end{array}$ & 6 & 3 & 1 & 0 \\
\hline & & $\begin{array}{l}\text { Students' knowledge and skills mastery } \\
\text { U422(0.675) }\end{array}$ & 6 & 2 & 1 & 1 \\
\hline & \multirow{2}{*}{$\mathrm{U} 43(0.202)$} & $\begin{array}{c}\text { Evaluate students objectively and } \\
\text { impartially } \\
\mathrm{U} 431(0.532) \\
\end{array}$ & 7 & 3 & 0 & 0 \\
\hline & & $\begin{array}{c}\text { Test the suitability of teaching objec- } \\
\text { tives and syllabus } \\
\text { U432(0.468) }\end{array}$ & 6 & 2 & 2 & 0 \\
\hline
\end{tabular}

According to the expert evaluation results, the sub-sets under the second-level in$\operatorname{dex} U_{11}$ (teaching files) are:

$$
R_{111}=\{0.6,0.3,0.1,0\}, R_{112}=\{0.7,0.2,0.1,0\}, R_{113}=\{0.7,0.1,0.2,0\} .
$$


Therefore, the FCE matrix of $U_{11}$ is:

$$
R_{11}=\left[\begin{array}{llll}
0.6 & 0.3 & 0.1 & 0 \\
0.7 & 0.2 & 0.1 & 0 \\
0.7 & 0.1 & 0.2 & 0
\end{array}\right] \text {. }
$$

After fuzzy comprehensive calculation, the second-level FCE set of $U_{1 l}$ is:

$$
\begin{aligned}
& B_{11}^{\prime}=w_{11} \times R_{11}=[0.334,0.270,0.525] \times R_{11} \\
& =\left[\begin{array}{llll}
0.6 & 0.3 & 0.1 & 0 \\
0.7 & 0.2 & 0.1 & 0 \\
0.7 & 0.1 & 0.2 & 0
\end{array}\right]=[0.7569,0.2067,0.1654,0]
\end{aligned}
$$

After normalization, there's: $B_{11}=[0.6704,0.1831,0.1465,0]$

Similarly, there are:

$$
\begin{aligned}
& B_{12}=[0.5428,0.3572,0.0572,0.0428], B_{13}=[0.45,0.25,0.25,0.05], \\
& B_{21}=[0.6117,0.3118,0.0661,0.0044], B_{22}=[0.6376,0.3,0.0624,0], \\
& B_{23}=[0.5305,0.2146,0.1943,0.0606], B_{24}=[0.7296,0.1557,0.1147,0] \\
& B_{31}=[0.55,0.25,0.2,0], B_{32}=[0.5574,0.3154,0.104,0.0233], \\
& B_{41}=[0.5387,0.300,0.1226,0.0387], B_{42}=[0.6,0.2325,0.1,0.0675], \\
& B_{43}=[0.6532,0.2532,0.0936,0] .
\end{aligned}
$$

Therefore, the first-level FCE matrix of first-level index $U_{l}$ (teaching preparation) is:

$$
R_{1}=\left[\begin{array}{l}
B_{11} \\
B_{12} \\
B_{13}
\end{array}\right]=\left[\begin{array}{cccc}
0.6704 & 0.1831 & 0.1465 & 0 \\
0.5428 & 0.3572 & 0.0572 & 0.0428 \\
0.45 & 0.25 & 0.25 & 0.05
\end{array}\right]
$$

After fuzzy comprehensive calculation, the first-level FCE set of first-level index $U_{l}$ (teaching preparation) is:

$$
\begin{aligned}
& B^{\prime}{ }_{1}=w_{1} \times R_{1}=[0.341,0.303,0.356] \times R_{1}=\left[\begin{array}{cccc}
0.6704 & 0.1831 & 0.1465 & 0 \\
0.5428 & 0.3572 & 0.0572 & 0.0428 \\
0.45 & 0.25 & 0.25 & 0.05
\end{array}\right] \\
& =[0.5533,0.2597,0.1563,0.0174]
\end{aligned}
$$


After normalization, there is:

$B_{1}=[0.5608,0.2632,0.1584,0.0177]$.

Similarly, there are:

$$
\begin{aligned}
& B_{2}=[0.6264,0.2464,0.1220,0.0052], B_{3}=[0.5542,0.2877,0.1446,0.0134], \\
& B_{4}=[0.5811,0.2693,0.1096,0.04] .
\end{aligned}
$$

Therefore, the FCE matrix of teaching evaluation is:

$$
R=\left[\begin{array}{l}
B_{1} \\
B_{2} \\
B_{3} \\
B_{4}
\end{array}\right]=\left[\begin{array}{llll}
0.5608 & 0.2632 & 0.1584 & 0.0177 \\
0.6264 & 0.2464 & 0.1220 & 0.0052 \\
0.5542 & 0.1446 & 0.0134 & 0.05 \\
0.5811 & 0.2693 & 0.1096 & 0.04
\end{array}\right] .
$$

The FCE set of teaching evaluation is:

$$
B^{\prime}=w \times R=[0.202,0.431,0.178,0.189] \times\left[\begin{array}{llll}
0.5608 & 0.2632 & 0.1584 & 0.0177 \\
0.6264 & 0.2464 & 0.1220 & 0.0052 \\
0.5542 & 0.1446 & 0.0134 & 0.05 \\
0.5811 & 0.2693 & 0.1096 & 0.04
\end{array}\right]
$$

$=[0.5808,0.2306,0.1077,0.0135]$

After normalization, there is: $B=[0.6288,2473,0.1155,0.0145]$.

The quantified comprehensive evaluation score is:

$$
S=B \times V^{T}=[0.6288,2473,0.1155,0.0145] \times\left[\begin{array}{c}
95 \\
85 \\
75 \\
65
\end{array}\right]=90.3615
$$

According to the quantified evaluation results, the comprehensive score of teacher A was 90.3615, which was between 90 and 100, and the evaluation grade was excellent. In order to better understand the strengths and weaknesses of this teacher, the model can also give FCE on each single index of the teacher. 


\section{Conclusions}

PE evaluation is helpful to improve the teaching level of PE teachers, increase the learning initiative of PE students, and finally realize the teaching goals of PE in schools. Based on FCE, this paper explored the influencing factors of PE evaluation, and obtained following conclusions:

1. By consulting expert opinions, this study established a new EIS for PE evaluation with 4 first-level indexes, 11 second-level indexes, and 28 third-level indexes.

2. AHP was applied to determine the weight values of indexes at each level, and a FCE model was constructed for PE evaluation.

3. With a college PE teacher A as an example, the application effect of the proposed EIS and FCE model was researched, and the results proved the feasibility and practicality of the model. The model not only can give quantified comprehensive evaluation of PE teaching, but also can give comprehensive evaluation on each single factor. The proposed model can reveal the real teaching situations from various aspects, and give reasonable suggestions targeting at each specific factor.

\section{Acknowledgement}

This work was supported by Heilongjiang Provincial Philosophy and Social Science Research Planning Annual Project (No. 18TYE567); Basic research project of basic scientific research business expenses of provincial colleges and universities in Heilongjiang Province (No. KYYWF10236190135); the 13th five-year plan research project on Education Science in Heilongiiang (No. GJC1319137); Research project on teaching reform in higher education in Heilongjiang (No. SJGY20200827).

\section{References}

[1] Chen, Z. (2021). Using big data fuzzy k-means clustering and information fusion algorithm in English teaching ability evaluation. Complexity, Article ID 5554444. https:// doi.org/10.1155/2021/5554444

[2] Yang, J., Shen, L., Jin, X., Hou, L., Shang, S., Zhang, Y. (2019). Evaluating the quality of simulation teaching in Fundamental Nursing Curriculum: AHP-Fuzzy comprehensive evaluation. Nurse education today, 77: 77-82. https://doi.org/10.1016/j.nedt.2019.03.012

[3] Zhu, W., Wan, M., Zhou, Y., Pan, W. (2018). Fuzzy computation of teaching performance based on data envelopment analysis method. Cognitive Systems Research, 52: 351-358. https://doi.org/10.1016/j.cogsys.2018.07.018

[4] Marasini, D., Quatto, P., Ripamonti, E. (2017). Inferential confidence intervals for fuzzy analysis of teaching satisfaction. Quality \& Quantity, 51(4): 1513-1529. https://doi.org/10. 1007/s11135-016-0349-7

[5] Liu, Y.R. (2020). An artificial intelligence and machine vision based evaluation of physical education teaching. Journal of Intelligent and Fuzzy Systems, 40(2): 3559-3569. https://doi.org/10.3233/jifs-189392 
[6] Yu, S. (2020). Application of computer information technology in college physical education using fuzzy evaluation theory. Computational Intelligence. https://doi.org/10. $\underline{1111 / \text { coin. } 12352}$

[7] Xu, Z. (2021). Teaching practice of environmental art design specialty based on fuzzy algorithm. Journal of Intelligent and Fuzzy Systems. https://doi.org/10.3233/jifs-189825

[8] Silverman, S., Manson, M. (2003). Research on teaching in physical education doctoral dissertations: a detailed investigation of focus, method, and analysis. Journal of Teaching in Physical Education, 22(3): 280-297. https://doi.org/10.1123/jtpe.22.3.280

[9] Bibik, J.M. (1999). Factors influencing college students' self-perceptions of competence in beginning physical education classes. Journal of Teaching in Physical Education, 18(3): 255-276. https://doi.org/10.1123/itpe.18.3.255

[10] Bao, L., Yu, P. (2021). Evaluation method of online and offline hybrid teaching quality of physical education based on mobile edge computing. Mobile Networks and Applications. https://doi.org/10.1007/s11036-021-01774-w

[11] Shan, D. (2021). The construction of a professional model of physical education teachers in colleges and universities from the perspective of public health service. Revista Brasileira de Medicina do Esporte, 27: 59-61. https://doi.org/10.1590/1517-869220212 $\underline{7012020 \_0093}$

[12] Ma, W., Wang, Y. (2017). Fuzzy comprehensive evaluation model of interuniversity collaborative learning based on network. Open Physics, 15(1): 427-432. https://doi.org/10. 1515/phys-2017-0047

[13] Imwold, C.H., Rider, R.A., Johnson, D.J. (1982). The use of evaluation in public school physical education programs. Journal of Teaching in Physical Education, 2(1): 13-18. https://doi.org/10.1123/jtpe.2.1.13

[14] Gibbons, S.L., Ebbeck, V. (1997). The effect of different teaching strategies on the moral development of physical education students. Journal of Teaching in Physical Education, 17(1): 85-98. https://doi.org/10.1123/jtpe.17.1.85

[15] Schiekirka, S., Raupach, T. (2015). A systematic review of factors influencing student ratings in undergraduate medical education course evaluations. BMC Medical Education, 15: 30. https://doi.org/10.1186/s12909-015-0311-8

[16] Johnson, T.G., Prusak, K.A., Pennington, T., Wilkinson, C. (2011). The effects of the type of skill test, choice, and gender on the situational motivation of physical education students. Journal of Teaching in Physical Education, 30(3): 281-295. https://doi.org/10. $\underline{1123 / \text { itpe.30.3.281 }}$

\section{Authors}

Min Tang was born in Songyuan, Jilin, China, in 1982. She received the master degree from Shenyang sport University, China. Now, she works in School of Sports, Suihua University, His research interest is athletic training.

Xiaoxue Si was born in Harbin, Heilongjiang, China, in 1997. He received the bachelor's degree from Suihua University, China. Now, he studies in School of Sports, Suihua University, His research interest is athletic training (email: shxypgzx@163.com).

Ruixue Wang was born in Hegang, Heilongjiang, China, in 1997. He received the bachelor's degree from Suihua University, China. Now, he studies in School of 
Sports, Suihua University, His research interest is athletic training (email: shxyfzghc @163.com).

Wenzhi Gao was born in Cangzhou, Hebei, China, in 1979. She received the master degree from Yanshan University, China. Now, she works in Physical Education Department; Suihua University, His research interest is higher education research (email: shxyjwc@126.com).

Article submitted 2021-07-15. Resubmitted 2021-08-01. Final acceptance 2021-08-05. Final version published as submitted by the authors. 